\title{
High yield expression of an AHL-lactonase from Bacillus sp. B546 in Pichia pastoris and its application to reduce Aeromonas hydrophila mortality in aquaculture
}

\author{
Ruidong Chen, Zhigang Zhou*, Yanan Cao, Yingguo Bai and Bin Yao*
}

\begin{abstract}
Background: Aeromonas hydrophila is a serious pathogen and can cause hemorrhagic septicemia in fish. To control this disease, antibiotics and chemicals are widely used which can consequently result in "superbugs" and chemical accumulation in the food chain. Though vaccine against A. hydrophila is available, its use is limited due to multiple serotypes of this pathogen and problems of safety and efficacy. Another problem with vaccination is the ability to apply it to small fish especially in high numbers. In this study, we tried a new way to attenuate the A. hydrophila infection by using a quorum quenching strategy with a recombinant AHL-lactonase expressed in Pichia pastoris.

Results: The AHL-lactonase (Aii $A_{B 546}$ ) from Bacillus sp. B546 was produced extracellularly in P. pastoris with a yield of 3,558.4 $\pm 81.3 \mathrm{U} / \mathrm{mL}$ in a 3.7-L fermenter when using 3-oxo-C8-HSL as the substrate. After purification with a HiTrap Q Sepharose column, the recombinant homogenous protein showed a band of $33.6 \mathrm{kDa}$ on SDS-PAGE, higher than the calculated molecular mass $\left(28.14 \mathrm{kDa}\right.$ ). Deglycosylation of Aii $A_{B 546}$ with Endo $\mathrm{H}$ confirmed the occurrence of $\mathrm{N}$ glycosylation. The purified recombinant $\mathrm{AiiA}_{\mathrm{B} 546}$ showed optimal activity at $\mathrm{pH} 8.0$ and $20^{\circ} \mathrm{C}$, exhibited excellent stability at pH 8.0-12.0 and thermal stability at $70^{\circ} \mathrm{C}$, was firstly confirmed to be significantly protease-resistant, and had wide substrate specificity. In application test, when co-injected with A. hydrophila in common carp, recombinant Aii $_{B 546}$ decreased the mortality rate and delayed the mortality time of fish.

Conclusions: Our results not only indicate the possibility of mass-production of AHL-lactonase at low cost, but also open up a promising foreground of application of AHL-lactonase in fish to control A. hydrophila disease by regulating its virulence. To our knowledge, this is the first report on heterologous expression of AHL-lactonase in P. pastoris and attenuating A. hydrophila virulence by co-injection with AHL-lactonase.
\end{abstract}

\section{Background}

Aeromonas hydrophila is a Gram-negative rod and behaves as an opportunistic pathogen in both aquatic and host environments [1-3]. It can cause hemorrhagic septicemia, resulting in fin and tail rot and epizootic ulcerative syndrome in juvenile and mature fish or intestinal and wound infection in humans [3-7]. Application of antibiotics and chemical drugs is a conventional method to con-

\footnotetext{
*Correspondence: zhou_zg@msn.com

,yaobin@caas-bio.net.cn

Key Laboratory for Feed Biotechnology of the Ministry of Agriculture, Feed Research Institute, Chinese Academy of Agricultural Sciences, Beijing 100081, PR China

Full list of author information is available at the end of the article
}

trol this disease, but generally results in the constant emergence of "superbugs" and chemical accumulation in the food chain $[8,9]$. Consequently, a new method is required to prevent such a fish disease $[8,10]$. Several studies have reported that vaccines against $A$. hydrophila infections may provide protection for farmed fish; however, no vaccines are commercially available due to multiple serotypes of this pathogen and problems of safety and efficacy $[11,12]$.

The pathogenicity of $A$. hydrophila depends on the production of potential virulence factors, such as exoproteases and exotoxin [13]. Production of exoproteases is under the control of quorum sensing $[1,6]$. The findings 
that $A$. hydrophila harbors the AhyI/AhyR quorum-sensing system, utilizes AHL-dependent quorum-sensing to regulate the expression of virulent genes, and mediates the process of microbial infection and colonization in the host provide a potentially promising strategy to control A. hydrophila--quorum-quenching $[1,6,7,10,13]$. Quorum-quenching mechanism has been identified in many prokaryotic and eukaryotic organisms [10]. It can regulate microbial activities of host by interfering with bacterial quorum sensing [14,15]. Many Gram-negative bacteria produce, secrete, and respond to small diffusible $\mathrm{N}$-acyl-homoserine lactone (AHL) signals to communicate with each other and determine group behaviors; for example, bacteria can sense their population density by the concentration of signal molecules and release toxins synchronously for disease outbreak $[16,17]$. Except for quorum-sensing inhibitors such as furanones and pyrrinones, degradation of quorum-sensing signals by quorum-quenching enzymes is another promising way [1719]. Quorum-quenching enzymes include AHL-lactonase, AHL-acylase and paraoxonases (PONs) [20-23]. AHL-lactonase, belonging to the metallohydrolase superfamily, catalyzes the hydrolysis of homoserine lactone ring of AHL signals $[24,25]$ and is widely conserved in a range of bacterial species [26]. Unlike AHL-acylase and PONs, which have variable substrate spectra, AHL-lactonase shows distinct substrate specificity and only efficiently hydrolyses AHL signals $[20,21,24]$.

The first AHL-degrading enzyme coding-gene (aiiA) was cloned from Bacillus sp. 240B1 and expressed in the plant pathogen Erwinia carotovora to attenuate E. carotovora pathogenicity by reducing AHL accumulation [23]. To date, AHL-lactonases from Bacillus spp. have been successfully obtained and expressed in several bacteria (i.e. plant pathogen E. carotovora, human pathogen Pseudomonas fluorescens, insecticide Bacillus thuringiensis and recombinant expression strain Escherichia coli) and plants (i.e. potato and tobacco) to quench quorum sensing of pathogens [27-31]. But little is known about the expression of AiiA in Pichia pastoris--a high-yield expression system [32-35]--and the use of AiiA in the form of enzyme preparation to quench quorum sensing of pathogens. Here, we cloned a gene from Bacillus sp. B546 encoding an AHL-lactonase and expressed the gene in P. pastoris to achieve high-yield production. A. hydrophila ATCC 7966, a type strain with the whole genome sequenced [7], is often related with hemorrhagic septicemia in cold-blooded animals including fish, reptiles, and amphibians [36] and was used to infect common carp (Cyprinus carpio carpio)--a popular pet fish--by co-injection with the recombinant AHL-lactonase. The attenuating effect of AHL-lactonase on the occurrence of hemorrhagic septicemia in fish was evaluated.

\section{Results}

\section{Gene cloning and sequence analysis}

Using the primers BT1 and BT2 designed specific for AHL-lactonases of Bacillus spp., the full-length 753-bp AHL-lactonase gene, aii $A_{\mathrm{B} 546}$, was cloned from Bacillus sp. B546. aii $A_{\mathrm{B} 546}$ encoded a 250 -amino acid polypeptide with a calculated molecular mass of $28.14 \mathrm{kDa}$ and a $p I$ of 4.64. No signal peptide was predicted in the deduced amino acid sequence of aii $_{\mathrm{B} 546}$ based on SignalP 3.0 analysis. One potential $\mathrm{N}$-glycosylation site (Asn-SerThr) was identified at the $\mathrm{N}$ terminus by NetNGlyc 1.0 Server. Aii $_{B 546}$ exhibited the maximum amino acid sequence identity (98\%) to the AHL-lactonase from $B$. thuringiensis followed by that of Bacillus sp. 240B1 (90\%).

\section{Expression and fermentation of recombinant $\mathrm{Aii}_{\mathrm{B} 546}$ in $\mathrm{P}$. pastoris}

The AHL-lactonase gene $a i i A_{\mathrm{B} 546}$ was transformed into $P$. pastoris GS115 competent cells with pPIC9 vector. Positive transformants were screened using well-diffusion assays, and the transformant with the highest AHL-lactonase activity was used for fermentation in the shake flask and 3.7-L fermenter. In the shake-flask level, AHL-lactonase activity was up to $27.1 \pm 3.2 \mathrm{U} / \mathrm{mL}$ after methanol induction at $25^{\circ} \mathrm{C}$ for $72 \mathrm{~h}$. In the fermenter, the expression level of recombinant $\mathrm{Aii}_{\mathrm{B} 546}$ gradually increased with the induction time, and reached 3,558.4 $\pm 81.3 \mathrm{U} /$ $\mathrm{mL}$ after $132 \mathrm{~h}$ induction (Figure 1 ).

\section{Purification of recombinant $A_{i i} A_{B 546}$ in shake-flasks}

Recombinant $\mathrm{Aii}_{\mathrm{B} 546}$ was purified to electrophoretic homogeneity by ammonium sulfate precipitation and anion exchange chromatography (Figure 2). The molecular weight of the purified $\mathrm{AiiA}_{\mathrm{B} 546}$ was $33.6 \mathrm{kDa}$ based on SDS-PAGE analysis, which was higher than the predicted value $(28.14 \mathrm{kDa})$. The protein concentration and AHLlactonase activity of the purified recombinant $\mathrm{AiiA}_{\mathrm{B} 546}$ was $0.006 \mathrm{mg} / \mathrm{mL}$ and $17.97 \pm 2.7 \mathrm{U} / \mathrm{mL}$, respectively.

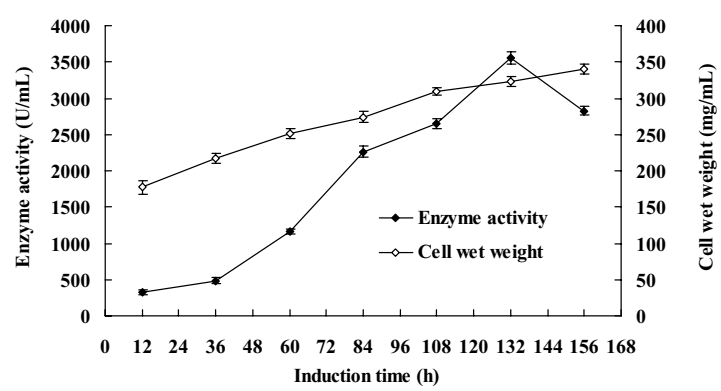

Figure 1 Accumulation of cell wet weight and enzymatic activity with methanol induction over time in a 3.7-L fermenter. 


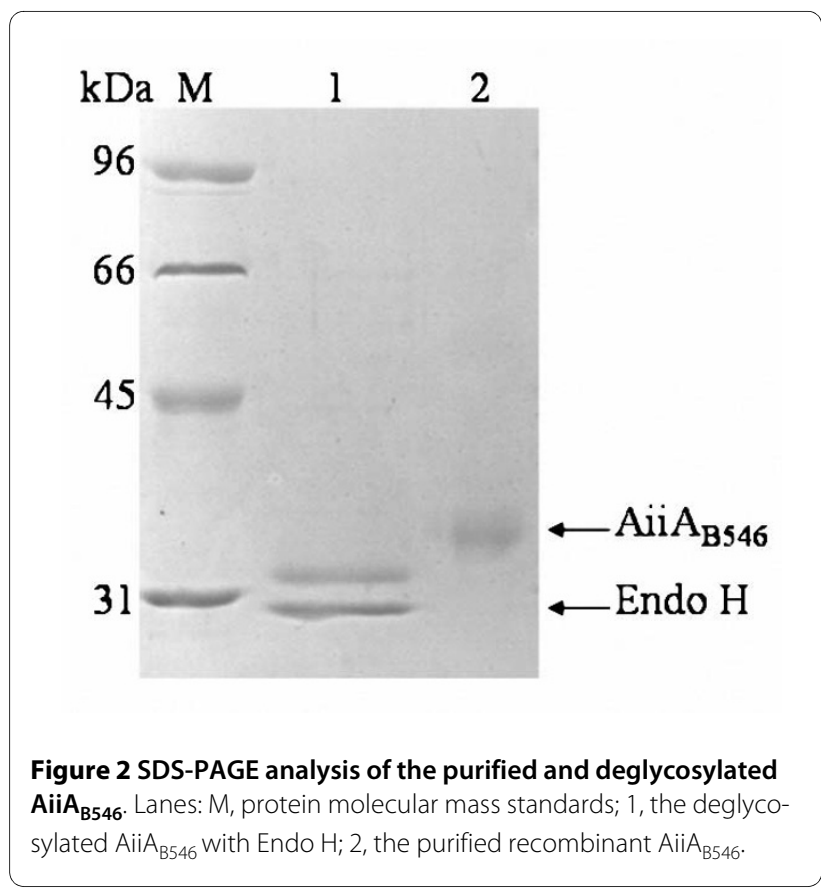

The specific activity of the purified recombinant $\mathrm{Aii}_{\mathrm{B} 546}$ was $2,995.3 \pm 61.7 \mathrm{U} / \mathrm{mg}$ with 3 -oxo-C8-HSL as the substrate.

\section{Deglycosylation and LC-ESI-MS/MS analysis}

After treatment with Endo H, the deglycosylated AiiA $\mathrm{B}_{\mathrm{B} 546}$ migrated as a single band of approximately $31.5 \mathrm{kDa}$ on SDS-PAGE (Figure 2), still higher than the predicted value. To confirm the identity of the purified protein, five interval peptides--KLYFVPAGR, MTEEDRIVNILKR, ENFEDEVPFAGVDSELALSSIKR, KENPIVFFGHDIEQEK and AEYETAQHSEEYLK--were obtained from LC-ESI-MS/MS analysis and shared 100\% identity with the deduced amino acid sequence of aii $_{\mathrm{B} 546}$.

\section{Enzyme characterization}

Purified recombinant Aii $_{\mathrm{B} 546}$ had the optimum $\mathrm{pH}$ of 8.0, and retained more than $73 \%$ of the maximum activity at $\mathrm{pH}$ 6.5-8.9 (Figure 3a). Recombinant Aii $_{\mathrm{B} 546}$ was stable at $\mathrm{pH}$ 6.0-12.0, retaining more than $70 \%$ activity after pre-incubation at $37^{\circ} \mathrm{C}$ for $1 \mathrm{~h}$ (Figure $3 \mathrm{~b}$ ). The optimum temperature of recombinant $\mathrm{Aii}_{\mathrm{B} 546}$ was $20^{\circ} \mathrm{C}$; at 0 and $20-35^{\circ} \mathrm{C}$, the enzyme maintained more than $60 \%$ of the highest activity (Figure 3c). Recombinant AiiA ${ }_{\mathrm{B} 546}$ exhibited thermal stability at $70^{\circ} \mathrm{C}$, retaining more than $80 \%$ of the initial activity after pre-incubation at $70^{\circ} \mathrm{C}$ for $30 \mathrm{~min}$ (Figure 3d). After storage at $0^{\circ} \mathrm{C}$ for 3 months, the enzyme still maintained $98.4 \%$ of the original activity.

The purified recombinant $\mathrm{Aii}_{\mathrm{B} 546}$ was protease-resistant (Figure 4). After incubation with trypsin, subtilisin A, collagenase and proleather at $37^{\circ} \mathrm{C}$ for 30 or $60 \mathrm{~min}$,
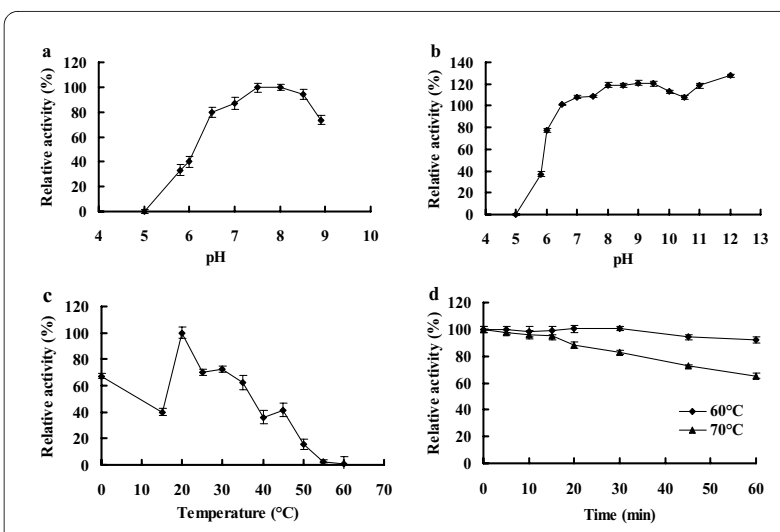

Figure 3 Enzyme characterization of purified recombinant

Aii $_{B 546}$. a: Effect of $\mathrm{pH}$ on the AHL-lactonase activity of $\mathrm{Aii}_{\mathrm{B546}}$. $\mathrm{b}$ : $\mathrm{pH}$ stability assay. After pre-incubating the enzyme at $25^{\circ} \mathrm{C}$ for $1 \mathrm{~h}$ in buffers of $\mathrm{pH}$ 5.0-12.0, the residual activity was measured in PBS buffer $(\mathrm{pH}$ 8.0) at $25^{\circ} \mathrm{C}$. c: Effect of temperature on AHL-lactonase activity. d: Thermostability of recombinant AiiA $A_{B 546}$. The enzyme was pre-incubated at 60 and $70^{\circ} \mathrm{C}$ in PBS buffer ( $\mathrm{pH} 8.0$ ), and aliquots were removed at specific time points for the measurement of residual activity at $25^{\circ} \mathrm{C}$.

the enzyme maintained or enhanced its enzymatic activity

The effect of different metal ions or chemical reagents on the activity of recombinant $\mathrm{Aii}_{\mathrm{B} 546}$ is displayed in Table 1. A number of metal ions, including $\mathrm{Na}^{+}, \mathrm{K}^{+}, \mathrm{Ca}^{2+}$, $\mathrm{Fe}^{3+}, \mathrm{Mn}^{2+}$, exhibited positive effects on the enzyme activity at 1 and $10 \mathrm{mM}$, respectively. AHL-lactonase activity was enhanced by $\mathrm{Mg}^{2+}, \mathrm{Zn}^{2+}$ and EDTA at $10 \mathrm{mM}$ but reduced at $1 \mathrm{mM}, \mathrm{Li}^{+}, \mathrm{Pb}^{2+}$ and $\beta$-mercaptoethanol promoted the enzyme activity at $1 \mathrm{mM}$ but reduced at 10 $\mathrm{mM}$. AHL-lactonase activity was significantly or completely inhibited by $\mathrm{Cu}^{2+}, \mathrm{Cr}^{3+}, \mathrm{SDS}, \mathrm{Hg}^{2+}$ and $\mathrm{Ag}^{+}$at both concentrations tested.

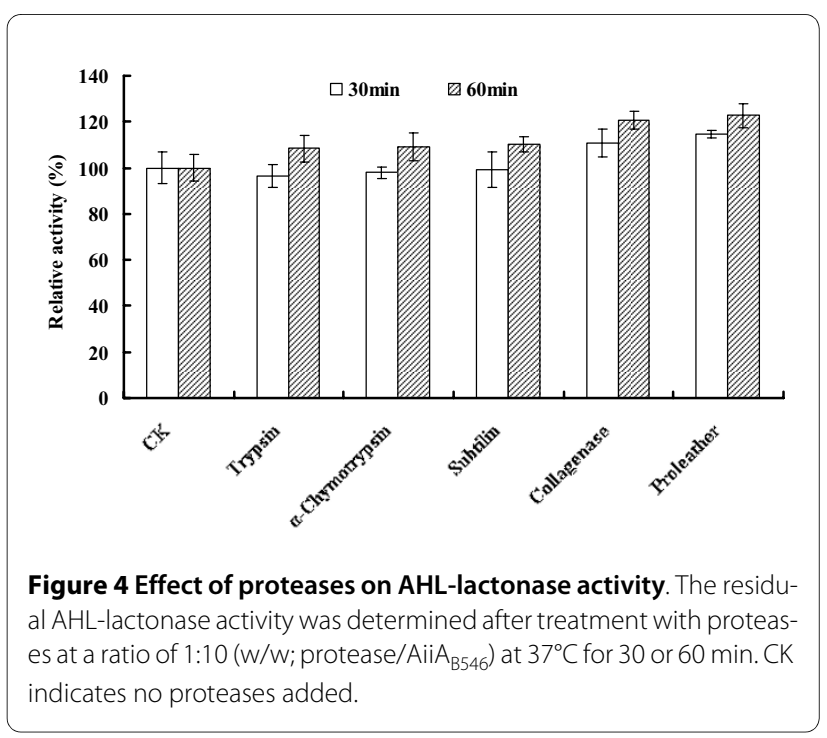


Table 1: Effects of metal ions and chemicals on the purified recombinant Aii $_{B 546}$ activity

\begin{tabular}{|c|c|c|c|c|c|}
\hline \multirow[t]{2}{*}{ Chemicals } & \multicolumn{2}{|c|}{ Relativity activity (\%)a } & \multirow[t]{2}{*}{ Chemicals } & \multicolumn{2}{|c|}{ Relativity activity (\%)a } \\
\hline & $1 \mathrm{mM}$ & $10 \mathrm{mM}$ & & $1 \mathrm{mM}$ & $10 \mathrm{mM}$ \\
\hline None & 100 & 100 & $\mathrm{Mg}^{2+}$ & $64.8 \pm 5.2^{*}$ & $108.4 \pm 2.5^{*}$ \\
\hline $\mathrm{Na}^{+}$ & $109.5 \pm 5.2^{*}$ & $104.6 \pm 2.4^{*}$ & $\mathrm{Fe}^{3+}$ & $104.8 \pm 2.6^{*}$ & $103.3 \pm 1.7^{*}$ \\
\hline $\mathrm{K}^{+}$ & $104.5 \pm 2.9^{*}$ & $109.3 \pm 6.1^{*}$ & $\mathrm{Zn}^{2+}$ & $89.3 \pm 4.2^{*}$ & $109.5 \pm 5.9^{*}$ \\
\hline $\mathrm{Ca}^{2+}$ & $106.5 \pm 3.7^{*}$ & $117.5 \pm 1.2^{*}$ & $\mathrm{Mn}^{2+}$ & $107.6 \pm 4.9^{*}$ & $108.4 \pm 5.8^{*}$ \\
\hline $\mathrm{Li}^{+}$ & $115.4 \pm 3.9^{*}$ & $65.8 \pm 5.4^{*}$ & $\mathrm{Ni}^{2+}$ & $103.4 \pm 4.4$ & $102.6 \pm 3.5$ \\
\hline $\mathrm{Co}^{2+}$ & $118.5 \pm 7.1^{*}$ & $103.8 \pm 4.3$ & $\mathrm{~Pb}^{2+}$ & $108.6 \pm 3.9^{*}$ & $87.5 \pm 3.6^{*}$ \\
\hline $\mathrm{Cu}^{2+}$ & $68.5 \pm 7.2^{*}$ & $58.8 \pm 5.4^{*}$ & EDTA & $66.5 \pm 2.5^{*}$ & $103.6 \pm 3.3^{*}$ \\
\hline $\mathrm{Cr}^{3+}$ & $29.1 \pm 4.2^{*}$ & $49.6 \pm 3.8^{*}$ & SDS & $73.2 \pm 4.2^{*}$ & $0.0 \pm 5.2^{*}$ \\
\hline $\mathrm{Ag}^{+}$ & $0.0 \pm 5.2^{*}$ & $0.0 \pm 3.7^{*}$ & $\beta$-Mercaptoethanol & $112.2 \pm 3.8$ & $92.0 \pm 5.1^{*}$ \\
\hline $\mathrm{Hg}^{2+}$ & $0.0 \pm 3.9^{*}$ & $0.0 \pm 4.9^{*}$ & & & \\
\hline
\end{tabular}

a Values represent the means $\pm S D(n=3)$ relative to the untreated control samples, and those marked with "*" are significantly different (oneway ANOVA; $P<0.05)$ from that of control without addition of chemicals.

Recombinant Aii $\mathrm{A}_{\mathrm{B} 546}$ exhibited catalytic activities towards all of the tested AHLs, including C10-HSL $(211,880 \mathrm{U} / \mathrm{mL})$, C12-HSL $(84,450 \mathrm{U} / \mathrm{mL})$, C6-HSL (19,030 U/mL), 3-oxo-C6-HSL (6,450 U/mL), 3-oxo-C8HSL (27.1 U/mL), and C8-HSL (3.32 U/mL).

\section{Co-injection of recombinant $A \mathrm{Aii}_{\mathrm{B} 546}$ and $\mathrm{A}$. hydrophila in common carp}

Aeromonas hydrophila ATCC 7966 was detected AHLs producing positive by reporter strain Agrobacterium tumefaciens KYC 55 (Figure 5). The $\mathrm{LD}_{50}$ of $A$. hydrophila to common carp was estimated at day 4 after intraperitoneal injection with $10^{8} \mathrm{cfu}$. When intraperitoneally injected with PBS buffer or AiiA $\mathrm{B}_{\mathrm{B} 46}$ only for 4 days, no mortalities or pathogenic symptoms were observed.

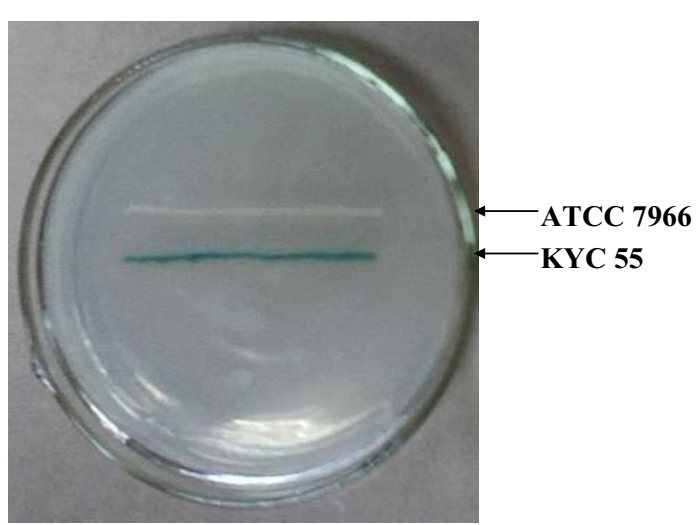

Figure 5 AHL production in A. hydrophila ATCC 7966. Screening of AHL production in A. hydrophila ATCC 7966 by reporter strain A. tumefaciens KYC55.
When intraperitoneally injected with $\mathrm{AiiA}_{\mathrm{B} 546}+$ A. hydrophila, the accumulated mortality at day 4 was $54.17 \pm$ $11.79 \%$, significantly lower than the average mortality rate (79.17 $\pm 5.89 \%)$ of the fish injected with $10^{8} \mathrm{cfu}$ of $A$. hydrophila $(P<0.05)$ (Figure 6). Co-injection of AiiA $\mathrm{B}_{\mathrm{B} 546}$ and $A$. hydrophila decreased the mortality rate of common carp by nearly $25 \%$. The $\mathrm{LT}_{50}$ of the fish injected with $A$. hydrophila was about $20 \mathrm{~h}$, which was delayed to $38 \mathrm{~h}$ by co-injection of $\mathrm{AiiA}_{\mathrm{B} 546}$ and A. hydrophila.

\section{Discussion}

AHLs-encoding genes (aiiA) have been expressed in several pathogens (i.e. E.carotovora and P. aeruginosa), plants (i.e. potato and tobacoo), B. thuringiensis and $E$.

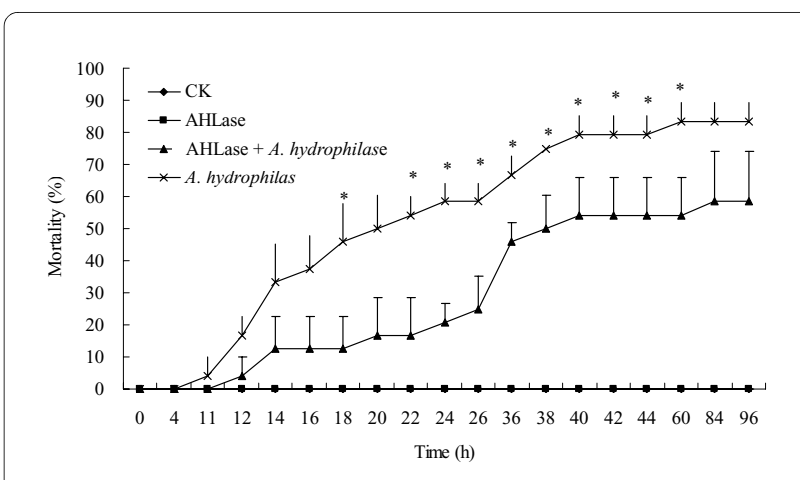

Figure 6 Average cumulative mortality rate in common carp of four treatments within $\mathbf{4}$ days. Average cumulative mortality rate in common carp inoculated with sterile PBS buffer (CK), Aii $A_{B 546}(0.4 \mathrm{U}), A$. hydrophila $\left(10^{8} \mathrm{cfu}\right)$ or $\mathrm{AiiA}_{\mathrm{B} 546}(0.4 \mathrm{U})+$ A. hydrophila $\left(10^{8} \mathrm{cfu}\right)$. Each point or bar represents the mean of triplicate plus standard deviation, and those marked with "*" means significant difference (one-way ANO$V A ; P<0.05)$ among the groups. 
coli [23,27-31]. Heterogenous expression of aiiA in pathogenic bacteria decreased the concentrations of auto-inducers, reduced the expression of several virulence factors (i.e. elastase and pyocyanin in P. aeruginosa) and attenuated the virulence of pathogens [23,28-30]. Expression of aiiA in the insecticide $B$. thuringiensis conferred the strain with a strong biocontrol capacity against AHL-dependent pathogen E. carotovora when co-inoculated with the pathogen [37]. aiiA was also expressed in $E$. coli and purified to study the specificity of the enzyme $[17,24]$. The recombinant $E$. coli was able to attenuate the pathogenicity of $E$. carotovora when co-inoculated together [17]. All of these results indicate that aiiA encoded a protein against bacterial pathogens by hampering their AHL-dependent quorum sense system. However, these transgenic strains have to be co-inoculated with AHL-dependent pathogens for disease control and consequently influence ecological security and the stable expression of aiiA in transgenic strains $[31,38]$. Considering the achievements and shortcomings of previous studies, we proposed two major innovations in this study. One is that we successfully overexpressed aiiA in $P$. pastoris for high-yield fermentation. To our knowledge, this is the first heterologous expression of aiiA in P. pastoris. The other is that we applied AHL-lactonase directly instead of AHL-lactonase-producing strains to control AHL-dependent pathogens of animals. Co-injection of Aii $_{\text {B546 }}$ with A. hydrophila in fish successfully attenuated the $A$. hydrophila infection. As far as we know, this is the first study to inject AHL-lactonase to control A. hydrophila infection in fish.

Expression of aii $A_{\mathrm{B} 546}$ in P. pastoris enhanced the production of $\mathrm{AiiA}_{\mathrm{B} 546}$ to $3,558.4 \pm 81.3 \mathrm{U} / \mathrm{mL}$, which was significantly higher than that expressed in E. coli $(0.24 \mathrm{U} /$ $\mathrm{mL}$, data of our lab work not published). In addition to high expression level, recombinant $\mathrm{Aii}_{\mathrm{B} 546}$ expressed in $P$. pastoris had more favorable properties for degrading AHLs in vivo. Firstly, recombinant $\mathrm{Aii}_{\mathrm{B} 546}$ had broad substrate specificity, showing catalytic activity against C4-HSL, C6-HSL, C8-HSL, C10-HSL, C12-HSL, C14HSL, 3-oxo-C6-HSL and 3-oxo-C8-HSL. Secondly, it showed preferable activity at the temperature range of $20-25^{\circ} \mathrm{C}$ and neutral and weak alkaline pHs, which are similar to the physicochemical conditions of the carp and their aquatic environment. Thirdly, recombinant $\mathrm{Aii}_{\mathrm{B} 546}$ expressed in P. pastoris was remarkably stable up to $70^{\circ} \mathrm{C}$, significantly better than that expressed in $E$. coli (retained $21.3 \%$ activity after incubation at $37^{\circ} \mathrm{C}$ for $30 \mathrm{~min}$, data of our lab work not published). This difference could be ascribed to the post-translation modification of recombinant AiiA ${ }_{\mathrm{B} 546}$ expressed in P. pastoris [39-41]. Deglycosylation with Endo $\mathrm{H}$ (Figure 2) confirmed the occurrence of $\mathrm{N}$-glycosylation, but didn't account for the complete weight difference. Except for $\mathrm{N}$-glycosylation, the recom- binant Aii $\mathrm{A}_{\mathrm{B} 46}$ expressed in P. pastoris may have other post-translation modifications, such as $O$-deglycosylation and phosphorylation. In addition to excellent thermodynamic stability, recombinant $\mathrm{AiiA}_{\mathrm{B} 546}$ also had other advantageous properties, such as protease-resistance, resistance to many metal ions, and excellent $\mathrm{pH}$ stability over a wide $\mathrm{pH}$ range. All these properties indicated the application potential of $\mathrm{Aii}_{\mathrm{B} 546}$ in aquaculture as a good feed additive $[42,43]$.

Many bacterial pathogens use AHL-dependent quorum sensing to regulate virulence, such as the animal pathogen $A$. hydrophila [1,3,6,13], plant pathogen E. carotovora [44] and mammalian pathogen $P$. aeruginosa [30,44]. AHL production in pathogen A. hydrophila ATCC 7966 has been screened by reporter strain KYC 55 (Figure 5). This result is consistent with that of the luxRI homologs of this strain detected by blot hybridization [45]. It has been reported that virulence factors such as extracellular proteases and $\alpha$-haemolysin are under the control of AHLs [6,13]. Co-injection of $\mathrm{AiiA}_{\mathrm{B} 546}$ and A. hydrophila in common carp decreased the mortality rate and delayed $\mathrm{LT}_{50}$ of the fish. The results indicated that $\mathrm{AiiA}_{\mathrm{B} 546}$ probably reduced the AHL accumulation of $A$. hydrophila, which would affect related gene expression and allow the host to build up defense mechanism against $A$. hydrophila infection, and eventually contributed to the decreased mortality rate and delayed $\mathrm{LT}_{50}$ of the carp observed in the present study $[1,6,15]$. After injection with the enzyme, fish displayed no signs of stress or disease and no mortalities were observed, thus indicating that the enzyme is safe for carp applications. We assume that the innate immune system of common carp might include some components like AiiA, because the PONs from human and other mammalian species have high catalytic activities against long-chain AHL signals and might be one of the active components of mammalian innate immune systems $[21,22,46,47]$. When incubated with $A$. hydrophila only, the fish began to die rapidly at $11 \mathrm{~h}$; coinjection of $A$. hydrophila with $\mathrm{AiiA}_{\mathrm{B} 546}$ delayed time to $26 \mathrm{~h}$. We conjectured that AiiA $\mathrm{B}_{\mathrm{B} 56}$ probably disrupted $A$. hydrophila transmission in the fish and prevented the pathogen from overcoming the host defenses by destroying the quorum sensing system of A. hydrophila. It has been reported that quorum sensing system was used by pathogens to escape premature detection of host defenses and defeat the host successfully at the appropriate time $[17,48,49]$. The detailed underlying mechanisms of this process, such as which AHLs are hydrolyzed and which virulence genes are hampered, need further study.

\section{Conclusions}

We firstly expressed an AHL-lactonase gene in P. pastoris and achieved high-yield fermentation of AHL-lactonase at low cost. The recombinant AHL-lactonase had prefer- 
able properties for practical application in aquaculture, such as favorable optimal $\mathrm{pH}$ and temperature, excellent $\mathrm{pH}$ and temperature stability, high specific activity, good protease-resistance and efficient hydrolysis of AHL signals. We tried a novel application form of AHL-lactonase and successfully controlled $A$. hydrophila infection in carp by using the quorum quenching strategy. Co-injection of AHL-lactonase with A. hydrophila decreased the mortality rate and delayed the $\mathrm{LT}_{50}$, indicating that the enzyme played an important role in attenuating $A$. hydrophila infection in fish and suggesting a promising way to control outbreaks of $A$. hydrophila disease in aquaculture. This recombinant enzyme with excellent $\mathrm{pH}$ and temperature stability and protease-resistance has potential application by feeding in the aquaculture. It is not clear if the same benefit will be observed, and further research about this enzyme in application will be carried out to make it more rigorously and clearly. Direct application of AHL-lactonase by either injection or feeding to control $A$. hydrophila infection might be an effective alternative of antibiotics to avoid the emergence of antibiotic-resistant strains.

\section{Materials and methods}

\section{Strains and culture conditions}

Bacillus sp. B546 was isolated from the mud of a fish pond at Wuqing, Tianjin, China using minimal medium [50] containing 3-oxo-C6-HSL as the sole carbon source at $30^{\circ} \mathrm{C}$ for 6 days. Strain B546 was identified by comparison of its $16 \mathrm{~S}$ rDNA sequence with known sequences in GenBank and preserved in the China General Microbiological Culture Collection (Beijing, China) under the registered number of CGMCC 3228.

Host strain P. pastoris GS115 was purchased from Invitrogen (USA). Minimal methanol medium, minimal dextrose medium, buffered glycerol-complex medium, buffered methanol-complex medium, fermentation basal salts medium, and PTM1 trace salts were prepared as described in the manual of the Pichia Expression Kit (Invitrogen).

Agrobacterium tumefaciens KYC 55 (pJZ372) (pJZ384) (pJZ410) [51] was used as reporter strain for AHLdegrading activity bioassay. The strain was cultivated at $28^{\circ} \mathrm{C}$ and $200 \mathrm{rpm}$ for $12 \mathrm{~h}$ in LB medium containing 100 $\mathrm{mg} / \mathrm{mL}$ spectinomycin, $100 \mathrm{mg} / \mathrm{mL}$ gentamicin, and 5 $\mathrm{mg} / \mathrm{mL}$ tetracycline.

Aeromonas hydrophila ATCC 7966 was grown in Mueller-Hinton agar (Oxoid; Canada) containing 5\% sheep erythrocytes at $30^{\circ} \mathrm{C}[52]$.

\section{Plasmids and reagents}

The pGEM-T Easy vector (Promega, USA) was used for gene cloning. Plasmid pPIC9 (Invitrogen) was used as expression vector. The DNA purification kit, restriction endonucleases and T4 DNA ligase were purchased from TaKaRa (Japan). Trypsin, $\alpha$-chymotrypsin, subtilisin A, collagenase and proleather were all purchased from Sigma (USA). C4-HSL, C6-HSL, 3-oxo-C6-HSL, C8-HSL, 3-oxo-C8-HSL, C10-HSL, C12-HSL, and C14-HSL were products of Sigma and used as substrates of AHL-lactonase. Other chemicals were of chemical grade and commercially available (Tiangen \& GreenFortune, China).

\section{Cloning and sequencing of the $\mathrm{AHL}$ lactonase gene aii $\mathrm{A}_{B 546}$} The genomic DNA of Bacillus sp. B546 was extracted by Bacterial genome extraction kit (Tiangen, China) following the manufacturer's instructions and used as the template for the PCR amplification. Based on the conserved amino acid sequences of AHL lactonases from Bacillus spp. and known information [23], a specific primer set was designed as follows: BT1 (5'-GCGGAATTCATGACAGTAAAGAAGCTTTATTTCG-3') and BT2 (5'ATAGCGGCCGCCTATATATACTCTGGGAACAC-3') (the EcoRI and NotI restriction sites are in blod). The PCR conditions included denaturation at $94^{\circ} \mathrm{C}$ for $5 \mathrm{~min}$; 30 cycles of $94^{\circ} \mathrm{C}, 30 \mathrm{~s}, 58^{\circ} \mathrm{C}, 30 \mathrm{~s}$, and $72^{\circ} \mathrm{C}, 1 \mathrm{~min}$; with a final extension at $72^{\circ} \mathrm{C}$ for $10 \mathrm{~min}$. The PCR product (about $750 \mathrm{bp}$ ) was purified and ligated into the pGEM-T Easy vector for sequencing and BLAST analysis.

\section{Sequence analysis}

The nucleotide sequence was analyzed by the Vector NTI Suite10 software. SignalP 3.0 server was used to predict the signal peptide in the deduced amino acid sequence http://www.cbs.dtu.dk/services/SignalP/. The DNA and protein sequences were aligned with known sequences by the blastn and blastp programs http:// www.ncbi.nlm.nih.gov/BLAST/, respectively. Glycosylation prediction was performed by NetOGlyc 3.1 and NetNGlyc 1.0 (http://www.cbs.dtu.dk/services/NetOGlyc, NetNGlyc).

\section{Expression of aiii $A_{B 546}$ in P. pastoris}

The recombinant pGEM-T Easy vector harboring aii $A_{\mathrm{B} 546}$ was digested by EcoRI and NotI, and cloned into the pPIC9 vector to construct the recombinant plasmid pPIC9-aii $A_{\mathrm{B} 546}$. The recombinant plasmid was linearized by digestion with $B g l \mathrm{II}$ and then transformed into $P$. pastoris GS115 by electroporation at $1.5 \mathrm{kV}$ in a $0.2-\mathrm{cm}$ cuvette. Then, $800 \mu \mathrm{L}$ ice-cold sorbitol solution was immediately added to the cuvette, and the mixture was incubated at $30^{\circ} \mathrm{C}$ for 3 days.

Positive transformants were further grown on minimal methanol and minimal dextrose plates at $30^{\circ} \mathrm{C}$ for 2 or 3 days. The selected transformants were inoculated into 3 $\mathrm{mL}$ buffered glycerol-complex medium and cultured at $30^{\circ} \mathrm{C}$ for $48 \mathrm{~h}$ with gentle shaking at $200 \mathrm{rpm}$. The cells were collected by centrifugation at 5,300 $\times g$ for $5 \mathrm{~min}$ at 
$4^{\circ} \mathrm{C}$ and suspended in $1 \mathrm{~mL}$ buffered methanol-complex medium. The cells were then cultured at $30^{\circ} \mathrm{C}$ and 200 $\mathrm{rpm}$ for $48 \mathrm{~h}$.

The culture supernatants were subjected to AHL-lactonase activity bioassay to select the clone with highest enzyme activity.

\section{AHL-lactonase activity bioassay}

Reporter strain A.tumefaciens KYC 55 was used to evaluate AHL-lactonase activity by using well-diffusion assays. Agar plates for bioassay were prepared by mixing $3 \mathrm{~mL}$ of the culture of $A$. tumefaciens KYC 55 and $20 \mathrm{~mL} \mathrm{LB}$ agar medium (1.2\% agar) at $45^{\circ} \mathrm{C}$ and immediately pouring into a $90-\mathrm{mm}$ petri dish at room temperature. Known volumes of 3-oxo-C8-HSL were added to the wells of 5$\mathrm{mm}$ diameter punched in the middle of the agar plates and incubated at $28^{\circ} \mathrm{C}$ for $12 \mathrm{~h}$. Sixty-microliter of $50 \mu \mathrm{g} /$ $\mathrm{mL} \mathrm{X-gal} \mathrm{was} \mathrm{spread} \mathrm{surrounding} \mathrm{the} \mathrm{wells} \mathrm{for} \mathrm{induction.}$ The diameter of induced zones was measured, and the relationship between the amounts of 3-oxo-C8-HSL (Y, $\mathrm{nM})$ and the square of radius $\left(\mathrm{X}, \mathrm{mm}^{2}\right)$ is: $\ln \mathrm{Y}=1.381 \mathrm{X}$ $10.528\left(r^{2}=0.9965\right)$. The reaction system $(200 \mu \mathrm{L})$ containing purified recombinant $\mathrm{AiiA}_{\mathrm{B} 546}(10 \mu \mathrm{L})$ and $24 \mathrm{nM}$ 3-oxo-C8-HSL in $50 \mathrm{mM}$ phosphate buffer (pH 8.0,) was incubated in a water bath at $25^{\circ} \mathrm{C}$ for $45 \mathrm{~min}$ and terminated by addition of $10 \%$ SDS to a final concentration of $2 \%$. The reaction mixture was pipetted into agar plate wells to determine the amount of residual 3-oxo-C8-HSL based on the established formula. The reaction system without Aii $_{\mathrm{B}_{546}}$ served as control. One unit (U) of AHLlactonase activity was defined as the amount of enzyme that hydrolyzed $1 \mathrm{nM}$ of 3-oxo-C8-HSL per minute under the assay conditions.

\section{Expression and purification of recombinant $\mathrm{Aii}_{\mathrm{B} 546}$ in shake flasks}

The clone with highest enzymatic activity was inoculated into $300 \mathrm{~mL}$ buffered glycerol-complex medium and cultured at $30^{\circ} \mathrm{C}$ for $48 \mathrm{~h}$ with gentle agitation at $200 \mathrm{rpm}$. The cells were collected by centrifugation at $5,300 \times g$, $4^{\circ} \mathrm{C}$ for $5 \mathrm{~min}$ and suspended in $100 \mathrm{~mL}$ buffered methanol-complex medium for growth at $30^{\circ} \mathrm{C}$ and $200 \mathrm{rpm}$ for $72 \mathrm{~h}$. The culture supernatant was collected at 10,000 $\times g$ at $4^{\circ} \mathrm{C}$ for $10 \mathrm{~min}$ and used for further purification.

Recombinant Aii $_{\mathrm{B} 546}$, in the culture supernatant was precipitated with $80 \%$ ammonium sulfate saturation, followed by centrifugation at $12,000 \times g$ for $10 \mathrm{~min}$, re-suspension in $20 \mathrm{mM}$ Tris- $\mathrm{HCl}$ ( $\mathrm{pH} 8.0$ ), and dialysis in the same buffer overnight. The crude enzyme was loaded onto a HiTrap Q Sepharose XL 5 mL FPLC column (GE Healthcare, Sweden) equilibrated with Tris- $\mathrm{HCl}$ buffer. Protein was eluted by a linear gradient of $\mathrm{NaCl}(0-1 \mathrm{M})$ at a flow rate of $3 \mathrm{~mL} / \mathrm{min}$. The fractions with AHL-lactonase activity were collected and identified on SDS-12\%
PAGE. The protein concentration of the purified recombinant AiiA $_{\mathrm{B} 546}$ was assayed by the Bradford method [53] with bovine serum albumin as standard. Enzyme activity of the purified recombinant $\mathrm{AiiA}_{\mathrm{B} 546}$ was measured by using well-diffusion assays (3-oxo-C8-HSL as the substrate).

\section{Deglycosylation and LC-ESI-MS/MS analysis}

The purified recombinant $\mathrm{AiiA}_{\mathrm{B} 546}$ was deglycosylated by Endo $\mathrm{H}$ at $37^{\circ} \mathrm{C}$ for $1 \mathrm{~h}$ following the manufacturer's instructions (New England Biolabs, USA). The deglycosylated enzyme was analyzed by SDS-PAGE. To identify the purified protein, the relevant protein band was excised from the SDS-PAGE gel, digested with trypsin, and analyzed by LC-ESI-MS/MS (Thermo Finnigan, USA). The results of LC-ESI-MS/MS were compared with the deduced amino acid sequence of $a i i A_{\mathrm{B} 546}$.

\section{Enzyme characterization of purified recombinant $\mathrm{AiiA}_{\mathrm{B} 546}$}

To study the enzyme properties of purified recombinant Aii $_{\text {B546 }}, 3$-oxo-C8-HSL was used as the substrate, and the reaction was carried out as described above.

The effect of $\mathrm{pH}$ on enzyme activity was determined at $25^{\circ} \mathrm{C}$ in buffers of $\mathrm{pH}$ ranging from 5.0 to 9.0 . To study the effect of $\mathrm{pH}$ on enzyme stability, the purified enzyme was pre-incubated in different buffers of $\mathrm{pH}$ ranging from 5.0 to 12.0 at $37^{\circ} \mathrm{C}$ for $1 \mathrm{~h}$ and measured the AHL-lactonase activity under standard conditions. The buffers used were $0.1 \mathrm{M}$ phosphate buffer for $\mathrm{pH}$ 5.0-8.0, 0.1 M Tris- $\mathrm{HCl}$ buffer for $\mathrm{pH}$ 8.0-9.0, and 0.1 $\mathrm{M}$ glycine- $\mathrm{NaOH}$ buffer for $\mathrm{pH}$ 9.0-12.0.

The optimum temperature of purified recombinant $\mathrm{AiiA}_{\mathrm{B} 546}$ was determined at the optimum $\mathrm{pH}$ over the temperature range from 0 to $60^{\circ} \mathrm{C}$. Thermal stability was determined by measuring the residual enzyme activity under standard conditions after pre-incubation in $0.1 \mathrm{M}$ phosphate buffer ( $\mathrm{pH} \mathrm{8.0)}$ at $60^{\circ} \mathrm{C}$ and $70^{\circ} \mathrm{C}$ for various durations.

The effects of various metal ions and chemical reagents on the enzymatic activity of purified recombinant Aii $_{\mathrm{B} 546}$ were examined at $25^{\circ} \mathrm{C}$ in $0.1 \mathrm{M}$ phosphate buffer ( $\mathrm{pH}$ 8.0) containing 1 or $10 \mathrm{mM}$ tested chemicals. The remaining enzyme activity was measured under the standard conditions as described above.

To determine resistance to proteolysis, purified recombinant $\mathrm{AiiA}_{\mathrm{B} 546}$ was incubated with either trypsin or $\alpha$ chymotrypsin in $0.1 \mathrm{M}$ Tris- $\mathrm{HCl}(\mathrm{pH} 7.0)$, collagenase or subtilisin A in $0.1 \mathrm{M}$ Tris- $\mathrm{HCl}$ ( $\mathrm{pH}$ 7.5), or proleather in $0.1 \mathrm{M}$ glycine- $\mathrm{NaOH}$ buffer $(\mathrm{pH} 10.0)$ at $37^{\circ} \mathrm{C}$ for different periods (30 or $60 \mathrm{~min}$ ) at a ratio of $1: 10(\mathrm{w} / \mathrm{w}$; protease/Aii $\left.\mathrm{A}_{\mathrm{B} 546}\right)$. Protease resistance was determined by measuring the residual enzyme activity after protease treatment. 
The substrate specificity of purified recombinant Aii $_{B 546}$ was studied by measuring the enzyme activity against AHLs with different acyl chain length and substitution. The substrates contained C6-HSL, C8-HSL, C10HSL, C12-HSL, 3-oxo-C6-HSL, and 3-oxo-C8-HSL.

\section{Fermentation of recombinant $\mathrm{AiiA}_{\mathrm{B} 546}$ in fermenter}

Fermentation of the clone with the highest AHL-lactonase activity in shake flask was performed in a 3.7-L fermenter (Bioengineering KLF 2000, Switzerland). The colony was cultured in $40 \mathrm{~mL}$ yeast peptone dextrose (YPD) medium at $30^{\circ} \mathrm{C}, 200 \mathrm{rpm}$ for $48 \mathrm{~h}$ and then transferred into $200 \mathrm{~mL} \mathrm{YPD}$ for growth $\left(30^{\circ} \mathrm{C}, 200 \mathrm{rpm}\right)$ overnight to prepare the fermentation seed. The seed was inoculated into 2-L of basal salt medium containing PTM1 trace salt solution in the 3.7-L fermenter. The temperature was set at $30^{\circ} \mathrm{C}$ and the $\mathrm{pH}$ was maintained at 5.0 with $28 \%(\mathrm{v} / \mathrm{v}) \mathrm{NH}_{3} \cdot \mathrm{H}_{2} \mathrm{O}$. The dissolved oxygen concentration was controlled by airflow and agitation.

The fermentation process was in reference of the Pichia Fermentation Process Guidelines (Invitrogen). Until the initial glucose in the fermentation medium was completely exhausted and the dissolved oxygen concentration level was up to $80 \%$, a glucose-fed batch phase was started by a $25 \%(\mathrm{w} / \mathrm{v})$ glycose feed at the rate of $36 \mathrm{~mL} / \mathrm{h} /$ $\mathrm{L}$ for $4 \mathrm{~h}$. In succession, the mixture containing 8:1 (v/v) $25 \%$ glucose/methanol was added at the rate of $9 \mathrm{~mL} / \mathrm{h} / \mathrm{L}$ for about $4 \mathrm{~h}$; during this phase, the cells adapted to grow in methanol. When the dissolved oxygen concentration increased notably, the mixture was replaced by $100 \%$ methanol to initiate the methanol fed-batch phase. The final concentration of $100 \%$ methanol was about $0.3 \%$ (v/ v) for $156 \mathrm{~h}$, and the recombinant protein was induced during this phase. In these three phases, the dissolved oxygen concentration was kept above $20 \%$.

During the induction and expression phase, culture samples were collected every day, and enzyme activity in the supernatant and cell wet weight were measured. The protein content in the supernatant was analyzed by SDSPAGE.

\section{Application in the control of bacterial disease in aquaculture}

Aermonas hydrophila ATCC 7966 and A. tumefaciens KYC 55 were streaked in parallel on LB plates containing $\mathrm{X}$-gal to screen strains producing AHL. Common carp of $1.3 \pm 0.15 \mathrm{~g}$ were raised at the density of 8 fish/tank $(10 \mathrm{~L} /$ tank) in an indoor recirculation aquaculture system with daily aeration by feeding with commercial dry food (Fishmeal $47.0 \%$, soybean meal $24.0 \%$, wheat flour $24.0 \%$, fish oil $2.0 \%, \mathrm{Ca}\left(\mathrm{H}_{2} \mathrm{PO}_{4}\right)_{2} 2.2 \%$, vitamin/mineral premix [54] $0.8 \%$; proximate composition: crude protein $42.0 \%$, crude lipid $7.2 \%$ ) at a fixed supply of $0.7 \%$ of their body weight every day [55]. The water temperature was kept constant at $28 \pm 1^{\circ} \mathrm{C}$.

Cells of A. hydrophila ATCC 7966 grown in MuellerHinton agar containing $5 \%$ sheep erythrocytes at $220 \mathrm{rpm}$ at $30^{\circ} \mathrm{C}$ for $12 \mathrm{~h}$ were washed with sterile PBS buffer $(\mathrm{pH}$ 7.3) three times, and suspended in PBS buffer as injection preparation. Purified recombinant $\mathrm{Aii}_{\mathrm{B} 546}$ was suspended in PBS buffer ( $\mathrm{pH}$ 7.3) before use.

To assess the lethal dose $50 \%\left(\mathrm{LD}_{50}\right)$ of $A$. hydrophila ATCC 7966, duplicated groups of 8 common carp (1.3 \pm $0.15 \mathrm{~g})$ were injected with $50 \mu \mathrm{L}$ of serial dilutions of $A$. hydrophila ranging from $2.0 \times 10^{8}$ to $2.0 \times 10^{10} \mathrm{cfu} / \mathrm{mL}$, and control groups were injected with the same volume of PBS (pH7.3). Cumulative mortality was recorded for 4 days.

To determine if recombinant aii $\mathrm{A}_{\mathrm{B} 546}$ had any influence on bacterial virulence, four treatments of common carp were designed and the fish of different groups injected intraperitoneally with $0.4 \mathrm{U} \mathrm{AiiA}_{\mathrm{B} 546}, 0.4 \mathrm{U} \mathrm{AiiA}_{\mathrm{B} 546}+A$. hydrophila of $10^{8} \mathrm{cfu}$ (AHLase + A. hydrophila), A. hydrophila of $10^{8} \mathrm{cfu}$ (A. hydrophila) or PBS buffer (control treatment) per fish in the volume of $50 \mu \mathrm{L}$ when anesthetized by tricaine methanesulfonate (MS-222). Each treatment included triplicate groups and each group contained 8 fish. The system was aerated, and any dead specimens were removed daily for routine bacteriological examination [56]. Cumulative mortality of each treatment was recorded about every two hours for 4 days.

\section{Nucleotide sequence accession number}

The nucleotide sequence for the $\mathrm{N}$-acyl homoserine lactonase gene (aiiA ${ }_{\text {B546 }}$ ) from Bacillus sp. B546 has been deposited in the Genbank under accession no. GQ899185.

\section{Abbreviations}

QS: quorum sensing; QQ: quorum quenching; AHLs: N-acyl homoserine lactones; AiiA: N-Acyl homoserine lactone lactonase; PONs: paraoxonases; YPD: yeast peptone dextrose medium; C4-HSL: N-butanoyl-L-homoserine lactone; C6-HSL: N-hexanoyl-L-homoserine lactone; 3-oxo-C6-HSL: N-(3-oxohexanoyl)L-homoserine lactone; C8-HSL: N-octanoyl-L-homoserine lactone; 3-oxo-C8HSL: N- $\beta$-oxooctanoyl-L-homoserine lactone; C10-HSL: N-decanoyl-L-homoserine lactone; C12-HSL: N-dodecanoyl-L-homoserinelactone; C14-HSL: N-3-tetradecanoyl-L- homoserine lactone; MS-222: tricaine methanesulfonate; Endo $\mathrm{H}$ : endo- $\beta$-N-acetylglucosaminidase $\mathrm{H}$; LC-ESI-MS/MS: liquid chromatographyelectrospray ionization-tandem mass spectrometry; AHLase: N-Acyl homoserine lactonase; $\mathrm{LD}_{50}$ : half lethal concentration; $\mathrm{LT}_{50}$ : half lethal time.

\section{Competing interests}

The authors declare that they have no competing interests.

\section{Authors' contributions}

RD performed the experiment and participated in data analysis and writing of the manuscript. $Z Z$ and $Y C$ participated in the design of the research and writing of the manuscript. YB performed fermentation of recombinant Aii $A_{B 546}$ in fermenter and participated in data analysis. BY participated in the design of the research and editorial supervision of the manuscript. All authors have read and approved the final version of the manuscript. 


\section{Acknowledgements}

We are grateful to professor Jun Zhu (Department of Microbiology, MOA Key Laboratory of Microbiological Engineering of Agricultural Environment, Nanjing Agricultural University, Nanjing, China) for providing the reporter stain A. tumefaciens KYC 55. The work was supported by State 863 High-Technology R\&D Project of China (2007AA100605).

\section{Author Details}

Key Laboratory for Feed Biotechnology of the Ministry of Agriculture, Feed Research Institute, Chinese Academy of Agricultural Sciences, Beijing 100081, PR China

Received: 19 March 2010 Accepted: 21 May 2010

Published: 21 May 2010

\section{References}

1. Swift S, Karlyshev AV, Fish L, Durant EL, Winson MK, Chhabra SR, Williams P, Macintyre S, Stewart GS: Quorum sensing in Aeromonas hydrophila and Aeromonas salmonicida: identification of the LuxRI homologs AhyRI and AsaRl and their cognate $\mathrm{N}$-acylhomoserine lactone signal molecules. Journal of Bacteriology 1997, 179:5271-5281.

2. Lynch MJ, Swift S, Kirke DF, Keevil CW, Dodd CE, Williams P: The regulation of biofilm development by quorum sensing in Aeromonas hydrophila. Environmental Microbiology 2002, 4:18-28.

3. Vivas J, Carracedo B, Riaño J, Razquin BE, López-Fierro P, Acosta F, Naharro $G$, Villena AJ: Behavior of an Aeromonas hydrophila aroA live vaccine in water microcosms. Applied and Environmental Microbiology 2004, 70:2702-2708

4. Froquet R, Cherix N, Burr SE, Frey J, Vilches S, Tomas JM, Cosson P: Alternative host model to evaluate Aeromonas virulence. Applied and Environmental Microbiology 2007, 73:5657-5659.

5. Reith ME, Singh RK, Curtis B, Boyd JM, Bouevitch A, Kimball J, Munholland J, Murphy C, Sarty D, Williams J, Nash JH, Johnson SC, Brown LL: The genome of Aeromonas salmonicida subsp. salmonicida A449: insights into the evolution of a fish pathogen. BMC Genomics 2008, 9:427.

6. Swift S, Lynch MJ, Fish L, Kirke DF, Tomás JM, Stewart GS, Williams P: Quorum sensing-dependent regulation and blockade of exoprotease production in Aeromonas hydrophila. Infection and Immunity 1999, 67:5192-5199.

7. Seshadri R, Joseph SW, Chopra AK, Sha J, Shaw J, Graf J, Haft D, Wu M, Ren Q, Rosovitz MJ, Madupu R, Tallon L, Kim M, Jin S, Vuong H, Stine OC, Ali A, Horneman AJ, Heidelberg JF: Genome sequence of Aeromonas hydrophila ATCC 7966T: jack of all trades. Journal of Bacteriology 2006, 188:8272-8282.

8. Williams $P$ : Quorum sensing: an emerging target for antibacterial chemotherapy? Expert Opinion on Therapeutic Targets 2002, 6:257-274.

9. Livermore DM: The need for new antibiotics. Clinical Microbiology and Infection 2004, 4:1-9.

10. Dong $Y H$, Wang $L Y$, Zhang $L H:$ Quorum-quenching microbial infections: mechanisms and implications. Philosophical Transactions of the Royal Society of London B: Biological Sciences 2007, 362:1201-1211.

11. Vivas J, Carracedo B, Riaño J, Razquin BE, López-Fierro P, Acosta F, Naharro $G$, Villena AJ: Behavior of an Aeromonas hydrophila aroA live vaccine in water microcosms. Applied and Environmental Microbiology 2004, 70:2702-2708

12. Hernanz Moral C, Flaño del Castillo E, López Fierro P, Villena Cortés A, Anguita Castillo J, Cascón Soriano A, Sánchez Salazar M, Razquín Peralta B, Naharro Carrasco G: Molecular characterization of the Aeromonas hydrophila aroA gene and potential use of an auxotrophic aroA mutant as a live attenuated vaccine. Infection and Immunity 1998, 66:1813-1821.

13. Sha J, Pillai L, Fadl AA, Galindo CL, Erova TE, Chopra AK: The type III secretion system and cytotoxic enterotoxin alter the virulence of Aeromonas hydrophila. Infection and Immunity 2005, 73:6446-6457.

14. Czajkowski R, Jafra S: Quenching of acyl-homoserine lactonedependent quorum sensing by enzymatic disruption of signal molecules. Acta Biochimica Polonicol 2009, 56:1-16.

15. Zhang LH: Quorum quenching and proactive host defense. Trends in Plant Science 2003, 8:238-244.

16. Fuqua $C$, Greenberg EP: Self perception in bacteria: quorum sensing with acylated homoserine lactones. Current Opinion of Microbiology 1998, 1:183-189.
17. Lee SJ, Park SY, Lee JJ, Yum DY, Koo BT, Lee JK: Genes encoding the $N$-acyl homoserine lactone-degrading enzyme are widespread in many subspecies of Bacillus thuringiensis. Applied and Environmental Microbiology 2002, 68:3919-3924.

18. Hentzer M, Wu H, Andersen JB, Riedel K, Rasmussen TB, Bagge N, Kumar N, Schembri MA, Song Z, Kristoffersen P, Manefield M, Costerton JW, Molin S, Eberl L, Steinberg P, Kjelleberg S, Høiby N, Givskov M: Attenuation of Pseudomonas aeruginosa virulence by quorum sensing inhibitors. EMBO Journal 2003, 22:3803-3815.

19. Wu H, Song Z, Hentzer M, Andersen JB, Molin S, Givskov M, Høiby N: Synthetic furanones inhibit quorum-sensing and enhance bacterial clearance in Pseudomonas aeruginosa lung infection in mice. Journal of Antimicrobial Chemotherapy 2004, 53:1054-1061.

20. Lin $\mathrm{YH}, \mathrm{Xu} J \mathrm{~L}, \mathrm{Hu} J$, Wang LH, Ong SL, Leadbetter JR, Zhang LH: Acylhomoserine lactone acylase from Ralstonia strain $\mathrm{XJ} 12 \mathrm{~B}$ represents a novel and potent class of quorum-quenching enzymes. Molecular Microbiology 2003, 47:849-860

21. Draganov DI, Teiber JF, Speelman A, Osawa Y, Sunahara R, La Du BN: Human paraoxonases (PON1, PON2, and PON3) are lactonases with overlapping and distinct substrate specificities. Journal of Lipid Research 2005, 46:1239-1247.

22. Yang F, Wang LH, Wang J, Dong YH, Hu JY, Zhang LH: Quorum quenching enzyme activity is widely conserved in the sera of mammalian species. FEBS Letters 2005, 579:3713-3717.

23. Dong $Y H$, Xu JL, Li XZ, Zhang LH: AiiA, an enzyme that inactivates the acylhomoserine lactone quorum-sensing signal and attenuates the virulence of Erwinia carotovora. Proceedings of National Academy of Sciences USA 2000, 97:3526-3531

24. Wang $L H$, Weng $L X$, Dong $Y H$, Zhang $L H$ : Specificity and enzyme kinetics of the quorum-quenching $\mathrm{N}$-Acyl homoserine lactone lactonase (AHLlactonase). Journal of Biological Chemistry 2004, 279:13645-13651.

25. Kim MH, Choi WC, Kang HO, Lee JS, Kang BS, Kim KJ, Derewenda ZS, Oh TK, Lee $\mathrm{CH}$, Lee JK: The molecular structure and catalytic mechanism of a quorum-quenching $\mathrm{N}$-acyl-L-homoserine lactone hydrolase. Proceedings of National Academy of Sciences USA 2005, 102:17606-17611.

26. Dong $\mathrm{YH}$, Zhang $\mathrm{LH}$ : Quorum sensing and quorum-quenching enzymes. Journal of Microbiology 2005, 43:101-109.

27. Dong $\mathrm{YH}$, Wang LH, Xu JL, Zhang HB, Zhang XF, Zhang LH: Quenching quorum-sensing-dependent bacterial infection by an $\mathrm{N}$-acyl homoserine lactonase. Nature 2001, 411:813-817.

28. Ulrich RL: Quorum quenching: enzymatic disruption of $\mathrm{N}$ acylhomoserine lactone-mediated bacterial communication in Burkholderia thailandensis. Applied and Environmental Microbiology 2004, 70:6173-6180

29. Molina L, Constantinescu F, Michel L, Reimmann C, Duffy B, Défago G: Degradation of pathogen quorum-sensing molecules by soil bacteria: a preventive and curative biological control mechanism. FEMS Microbiology Ecology 2003, 45:71-81.

30. Reimmann C, Ginet N, Michel L, Keel C, Michaux P, Krishnapillai V, Zala M, Heurlier K, Triandafillu K, Harms H, Défago G, Haas D: Genetically programmed autoinducer destruction reduces virulence gene expression and swarming motility in Pseudomonas aeruginosa PAO1. Microbiology 2002, 148:923-932

31. Zhang L, Ruan L, Hu C, Wu H, Chen S, Yu Z, Sun M: Fusion of the genes for AHL-lactonase and S-layer protein in Bacillus thuringiensis increases its ability to inhibit soft rot caused by Erwinia carotovora. Applied Microbiology and Biotechnology 2007, 74:667-675.

32. Kocken CH, Dubbeld MA, Wel A Van Der, Pronk JT, Waters AP, Langermans JA, Thomas AW: High-level expression of Plasmodium vivax apical membrane antigen 1 (AMA-1) in Pichia pastoris: strong immunogenicity in Macaca mulatta immunized with P. vivax AMA-1 and adjuvant SBAS2. Infection and Immunity 1999, 67:43-49.

33. Kocken $\mathrm{CH}$, Withers-Martinez $\mathrm{C}$, Dubbeld MA, Wel A van der, Hackett F, Valderrama A, Blackman MJ, Thomas AW: High-level expression of the malaria blood-stage vaccine candidate Plasmodium falciparum apical membrane antigen 1 and induction of antibodies that inhibit erythrocyte invasion. Infected Immunity 2002, 70:4471-4476.

34. Loukas A, Bethony JM, Mendez S, Fujiwara RT, Goud GN, Ranjit N, Zhan B, Jones K, Bottazzi ME, Hotez PJ: Vaccination with recombinant aspartic hemoglobinase reduces parasite load and blood loss after hookworm infection in dogs. PLoS Medicine 2005, 2:e295. 
35. Liu YY, Woo JH, Neville DM Jr: Overexpression of an anti-CD3 immunotoxin increases expression and secretion of molecular chaperone BiP/Kar2p by Pichia pastoris. Applied and Environmental Microbiology 2005, 71:5332-5340.

36. Austin B, Austin D: Bacterial Fish Pathogens: Disease in Farmed and Wild Fish. Third Revised edition. Ellis Horwood, Chichester; 1987.

37. Dong YH, Zhang XF, Xu JL, Zhang LH: Insecticidal Bacillus thuringiensis silences Erwinia carotovora virulence by a new form of microbial antagonism, signal interference. Applied and Environmental Microbiology 2004, 70:954-960.

38. Muir J: Managing to harvest? Perspectives on the potential of aquaculture. Philosophical Transactions of the Royal Socienty of London, Series B: Biological Science 2005, 360:191-218.

39. Shental-Bechor D, Levy Y: Effect of glycosylation on protein folding: a close look at thermodynamic stabilization. Proceedings of National Academy of Sciences USA 2008, 105:8256-8261.

40. Kern G, Schülke N, Schmid FX, Jaenicke R: Stability, quaternary structure, and folding of internal, external, and core-glycosylated invertase from yeast. Protein Science 1992, 1:120-131.

41. Blanchard V, Gadkari RA, George AV, Roy S, Gerwig GJ, Leeflang BR, Dighe RR, Boelens R, Kamerling JP: High-level expression of biologically active glycoprotein hormones in Pichia pastoris strains-selection of strain GS115, and not X-33, for the production of biologically active $\mathrm{N}$ glycosylated 15N-labeled phCG. Glycoconj Journal 2008, 25:245-257.

42. Mi S, Meng K, Wang Y, Bai Y, Yuan T, Luo H, Yao B: Molecular cloning and characterization of a novel a-galactosidase gene from Penicillium sp. F63 CGMCC 1669 and expression in Pichia pastoris. Enzyme and Microbial Technology 2007, 7848:1-8.

43. Li N, Shi P, Yang P, Wang Y, Luo H, Bai Y, Zhou Z, Yao B: Cloning, expression, and characterization of a new Streptomyces sp. S27 xylanase for which xylobiose is the main hydrolysis product. Applied Biochemistry and Biotechnology 2009, 159:521-531.

44. Jones S, Yu B, Bainton NJ, Birdsall M, Bycroft BW, Chhabra SR, Cox AJ, Golby P, Reeves PJ, Stephens S, Winson MK, Salmond GPC, Stewart GSAB, Williams $P$ : The lux autoinducer regulates the production of exoenzyme virulence determinants in Erwinia carotovora and Pseudomonas aeruginosa. EMBO Journal 1993, 12:2477-2482.

45. Jangid K, Kong R, Patole MS, Shouche YS: lux RI homologs are universally present in the genus Aeromonas. BMC Microbiology 2007, 7:93.

46. Chun CK, Ozer EA, Welsh MJ, Zabner J, Greenberg EP: Inactivation of a Pseudomonas aeruginosa quorum-sensing signal by human airway epithelia. Proceedings of the National Academy of Sciences USA 2004, 101:3587-3590.

47. Ozer EA, Pezzulo A, Shih DM, Chun C, Furlong C, Lusis AJ, Greenberg EP, Zabner J: Human and murine paraoxonase 1 are host modulators of Pseudomonas aeruginosa quorum-sensing. FEMS Microbiology Letters 2005, 253:29-37.

48. Mäe A, Montesano M, Koiv V, Palva ET: Transgenic plants producing the bacterial pheromone $\mathrm{N}$-acyl-homoserine lactone exhibit enhanced resistance to the bacterial phytopathogen Erwinia carotovora. Molecular Plant and Microbe Interaction 2001, 14:1035-1042.

49. Fray RG, Throup JP, Daykin M, Wallace A, Williams P, Stewart GS, Grierson $D$ : Plants genetically modified to produce $N$-acylhomoserine lactones communicate with bacteria. National Biotechnology 1999, 17:1017-1020.

50. Leadbetter JR, Greenberg EP: Metabolism of acyl-homoserine lactone quorum-sensing signals by Variovorax paradoxus. Journal of Bacteriology 2000, 182:6921-6926.

51. Zhu J, Chai Y, Zhong Z, Li S, Winans SC: Agrobacterium bioassay strain for ultrasensitive detection of $\mathrm{N}$-acylhomoserine lactone-type quorum-sensing molecules: detection of autoinducers in Mesorhizobium huakuii. Applied and Environmental Microbiology 2003, 69:6949-6953

52. Wang G, Clark CG, Liu C, Pucknell C, Munro CK, Kruk TMAC, Caldeira R, Woodward DL, Rodgers FG: Detection and characterization of the hemolysin genes in Aeromonas hydrophila and Aeromonas sobria by multiplex PCR. Journal of Clinical Microbiology 2003, 41:1048-1054.

53. Bradford MM: A rapid and sensitive method for the quantitation of microgram quantities of protein utilizing the principle of protein-dye binding. Analysis of Biochemstry 1976, 72:248-254.

54. Lv H, Zhou Z, Rudeaux F, Respondek F: Effects of dietary short chain fructo-oligosaccharides on intestinal microflora, mortality and growth performance of 0 . nilotica $q \times 0$. aurea $O^{\prime}$. Chinese Journal of Animal Nutrition 2007, 19:691-697.

55. Mazon AF, Huising MO, Taverne-Thiele AJ, Bastiaans J, Verburg-van Kemenade BM: The first appearance of Rodlet cells in carp (Cyprinus carpio $L$.) ontogeny and their possible roles during stress and parasite infection. Fish and Shellfish Immunology 2007, 22:27-37.

56. Li Y, Cao H, He S, Yang X: Isolation and identification of Aeromonas hydrophila strain X1 from Acipenser baerii and its antibiotic sensitivity. Volume 38. Institute of Microbiology, CAS; 2008:1186-1191.

doi: 10.1186/1475-2859-9-39

Cite this article as: Chen et al., High yield expression of an AHL-lactonase from Bacillus sp. B546 in Pichia pastoris and its application to reduce Aeromonas hydrophila mortality in aquaculture Microbial Cell Factories 2010, 9:39

\section{Submit your next manuscript to BioMed Central} and take full advantage of:

- Convenient online submission

- Thorough peer review

- No space constraints or color figure charges

- Immediate publication on acceptance

- Inclusion in PubMed, CAS, Scopus and Google Scholar

- Research which is freely available for redistribution

Submit your manuscript at www.biomedcentral.com/submit
C Biomed Central 